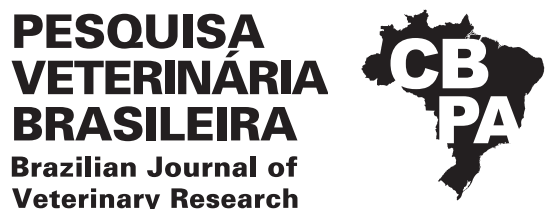

Pesq. Vet. Bras. 41:e06857, 2021

DOI: 10.1590/1678-5150-PVB-6857

Original Article

Livestock Diseases

ISSN 0100-736X (Print)

ISSN 1678-5150 (Online)

\title{
Causes of death of sows in three Brazilian pig farms ${ }^{1}$
}

\author{
Claiton I. Schwertz ${ }^{2 *}$ (D), Ronaldo Michel Bianchi², Bianca S. Cecco² (D), \\ Saulo P. Pavarini ${ }^{2}$ (D) and David Driemeier ${ }^{2}$ (D)
}

\begin{abstract}
Schwertz C.I., Bianchi R.M., Cecco B.S., Pavarini S.P. \& Driemeier D. 2021. Causes of death of sows in three Brazilian pig farms. Pesquisa Veterinária Brasileira 41:e06857, 2021. Setor de Patologia Veterinária, Faculdade de Veterinária, Universidade Federal do Rio Grande do Sul, Av. Bento Gonçalves 9090, Porto Alegre, RS 91540-000, Brazil. E-mail: claiton.schwertz@outlook.com

Sow mortality is directly related to financial losses and productive efficiency in pig farms. Despite this, diseases associated with the death of sows are poorly understood. This study aimed to determine the main causes of death of sows in Brazilian pig farms. To perform this research, three Brazilian pig farms were visited, and necropsies were performed on all sows that had died spontaneously or were subjected to euthanasia. Tissue fragments were collected for histopathological and bacteriological examination. In addition, the clinical signs, productive stage, parity, and type of death (spontaneous or euthanasia) were recorded. A total of 138 necropsies were performed, and 132 had a conclusive diagnosis. The most frequent productive stages were gestation and lactation (33.3 and 31.9\%, respectively), followed by parturient sows (17.4\%), cull sows (9.4\%), weaning-to-estrus interval (WEI) $(4.3 \%)$, and unmated gilts (3.6\%). The most affected organ systems were reproductive (28\%), digestive (25\%), locomotor (22\%), cardiovascular (9.1\%), and hematopoietic (6.1\%). The most frequently diagnosed conditions were uterine prolapse $(16 / 132 ; 12.1 \%)$, gastric ulcer (13/132; 9.8\%), suppurative arthritis (11/132; 8.3\%), liver lobe torsion (11/132; $8.3 \%)$, heart failure $(9 / 132 ; 6.8 \%)$, vaginal or vaginal and rectal prolapse $(9 / 132 ; 6.8 \%)$, and pododermatitis $(8 / 132 ; 6.1 \%)$. Although $58.2 \%$ of the deaths were due to one of these seven diseases, there was a great variability in diagnoses.
\end{abstract}

INDEX TERMS: Sows, swine, pig farms, diseases of swine, sow mortality, prolapse, gastric ulcer, liver lobe torsion, Brazil.

\begin{abstract}
RESUMO.- [Causas de morte de matrizes suínas em três granjas brasileiras.] A mortalidade de porcas está diretamente relacionada a perdas financeiras e à eficiência produtiva das granjas. Apesar disso, as doenças associadas à morte de porcas são pouco conhecidas. Este estudo teve como objetivo determinar as principais causas de morte de porcas em granjas suinícolas brasileiras. Para a realização desta pesquisa, três granjas brasileiras foram visitadas e necropsias foram realizadas em todas as porcas que morreram espontaneamente ou foram submetidas à eutanásia. Fragmentos de tecidos foram coletados para exame histopatológico e bacteriológico. Além disso, foram registrados os sinais clínicos, estágio reprodutivo, ordem de parto e tipo de morte (espontânea ou eutanásia). Um total de 138 necropsias foram
\end{abstract}

\footnotetext{
${ }^{1}$ Received on July 11, 2021.

Accepted for publication on August 17, 2021.

${ }^{2}$ Setor de Patologia Veterinária, Faculdade de Veterinária, Universidade Federal do Rio Grande do Sul (UFRGS), Av. Bento Gonçalves 9090, Porto Alegre, RS 91540-000, Brazil. *Corresponding author: claiton.schwertz@outlook.com
}

realizadas e 132 tiveram um diagnóstico conclusivo. Os estágios produtivos mais frequentes foram gestação e lactação (33,3 e $31,9 \%$, respectivamente), seguidos por porcas parturientes $(17,4 \%)$, porcas de descarte $(9,4 \%)$, intervalo desmame-estro (IDE) $(4,3 \%)$ e leitoas vazias $(3,6 \%)$. Os sistemas orgânicos mais afetados foram reprodutor (28\%), digestivo (25\%), locomotor $(22 \%)$, cardiovascular $(9,1 \%)$ e hematopoiético $(6,1 \%)$. As condições mais frequentemente diagnosticadas foram prolapso uterino $(16 / 132 ; 12,1 \%)$, úlcera gástrica $(13 / 132 ; 9,8 \%)$, artrite supurativa (11/132; 8,3\%), torção do lobo hepático (11/132; 8,3\%), insuficiência cardíaca (9/132; $6,8 \%)$, prolapso vaginal ou prolapso vaginal e retal ( $9 / 132$; $6,8 \%$ ) e pododermatite (8/132; 6,1\%). Embora $58,2 \%$ dos óbitos tenham ocorrido por uma dessas sete doenças, houve grande variabilidade de diagnósticos.

TERMOS DE INDEXAÇÃO: Porcos, suínos, doenças de suínos, mortalidade de porcas, prolapso, úlcera gástrica, torção do lobo hepático, Brasil. 


\section{INTRODUCTION}

The sow mortality rate in a pig farm represents an important productive data, since it is directly related to financial losses and efficiency of the pig farms (Engblom et al. 2007, Morés 2007). The financial losses related to the death of a sow include the partial loss of genetic value, the cost of replacement gilts, the lack of income from slaughter, along with other operational costs and lost profits (Morés 2007, Engblom et al. 2008). The diseases that affect sows also have an impact on animal welfare and on the motivation of people involved in the productive process (Morés 2007, Sanz et al. 2007).

Except for disease outbreaks, sow deaths are often neglected (Abiven et al. 1998). The available data is often provided by companies and is based on the observation of farm workers, according to their presumptive diagnosis, with a high proportion of unknown causes (D'Allaire et al. 1991, Palomo 2006). In Brazil, there have been very few comprehensive studies based on the causes of death of sows on pig farms, and high mortality rates are common (Morés 2007, Vearick et al. 2008). This study characterize the epidemiological, clinical, and pathological aspects of the main diseases diagnosed as causes of death of sows in Brazilian pig farms.

\section{MATERIALS AND METHODS}

Three sow operations (Farms A, B and C) located in different Brazilian states were visited. Farm A, located in Santa Catarina state, was an 8,500-sow unit. Two visits were made to this farm, the first one in August 2016 and the second in February 2017. Farm B, a 16,500sow operation, located in Mato Grosso state, was visited in August 2017. Farm C was located in Paraná. It was a 2,750-sow farm and was visited in November 2017. The annual sow mortality rate at these farms at the time of the investigation was 9.8, 9.5, and $15 \%$, respectively. On each farm visit, an average of 12 days was spent accumulating data, during which necropsies were performed on all sows that had died or were euthanized due to humanitarian reasons.

During the necropsies, tissue fragments were collected, including brain, muscles, urinary bladder, and the main viscera of abdominal and thoracic cavities, fixed in a $10 \%$ formalin solution, routinely processed for histopathology, and stained by hematoxylin and eosin (HE). When there was a suspicion of bacterial disease, tissue fragments and body fluids were collected and sent for microbiological analysis. Samples for bacteriological culture were grown on MacConkey and blood agar plates and incubated in an aerobic medium at $37^{\circ} \mathrm{C}$.

The presumptive diagnosis based on macroscopic findings was recorded, as well as the clinical signs reported by farm workers, parity, and other information present on the sow individual form. In addition, the type of death was classified as euthanasia or spontaneous, the productive stage as gestation, lactation, weaning-to-estrus interval (WEI), parturient (females that died during farrowing), unmated gilts, and cull sows (females removed from the reproductive herd).

Data from the three farms were grouped and analyzed together. The frequency of each disease was calculated based on the conclusive diagnoses, in addition to the median and mean parity of sows of each group, and the proportion of cases within each organ system. The information collected about the seven diseases with the highest frequency of diagnoses was analyzed separately, aiming to characterize some relevant aspects of each condition.

\section{RESULTS}

During the period of study, 138 sow necropsies were performed, 56 in Farm A; 60 in Farm B; and 22 in Farm C. In 132 cases, a conclusive diagnosis was obtained (95.6\%) and six cases $(4.4 \%)$ were inconclusive. The data from the three farms were grouped and analyzed together. The productive stages of the necropsied sows are represented in Figure 1, along with the distribution of the most diagnosed diseases by productive stage. The average parity was 3.4 (range from 0 to 12 ), and the median was three. Death was spontaneous in $63.8 \%$ of sows $(88 / 138)$ and $36.2 \%(50 / 138)$ were euthanized by farm employees because of humanitarian reasons. The conditions diagnosed are presented in Table 1, along with the frequency of diagnoses, the mean and median parity of the affected sows and subdivision by organ systems.

Uterine prolapse was the most frequent cause of death (16 cases) and affected parturient (87.5\%) or early lactating sows $(12.5 \%)$. The mean parity was 5.1 (range 2 to 10$)$. The prolapsed segments presented congestion with areas of hemorrhage and deposition of fibrin on the mucosa (Fig.2).

Gastric ulcer was the second leading cause of death with 13 cases. The affected categories were gestation (46.2\%), lactation (38.5\%), and cull (15.4\%). From these, six were euthanized (46.2\%) and seven (53.8\%) died spontaneously. Young sows were most affected, since $76.9 \%$ were parity 1 or 2 . The clinical and pathological presentation of the gastric ulcers varied from peracute to chronic cases. Peracute cases were characterized by sudden death due to the loss of a large volume of blood. Acute and subacute cases of gastric ulcers were characterized by melena, vomiting, pallor skin, and hyporexia lasting from a few days to weeks (Fig.3). Chronic cases were characterized by severe weight loss, secondary to fibrosis and stenosis of the pars esophagea (Fig.4). Two sows with gastric ulcers developed peritonitis secondary to perforation of the stomach wall.

Suppurative arthritis was an important reason for euthanasia of sows in this study, with 11 cases. This condition occurred more frequently during gestation (54.5\%) and affected sows from different parities. Trueperella pyogenes was isolated in six $(54.5 \%)$ cases of arthritis, Streptococcus spp. in three $(27.3 \%)$, both in pure culture, and in two cases $(18.2 \%)$ there was no bacterial growth. The affected joints contained purulent material, necrosis of the synovial membrane, thickening of the joint capsule by fibrosis (Fig.5), and in two cases, necrosis of

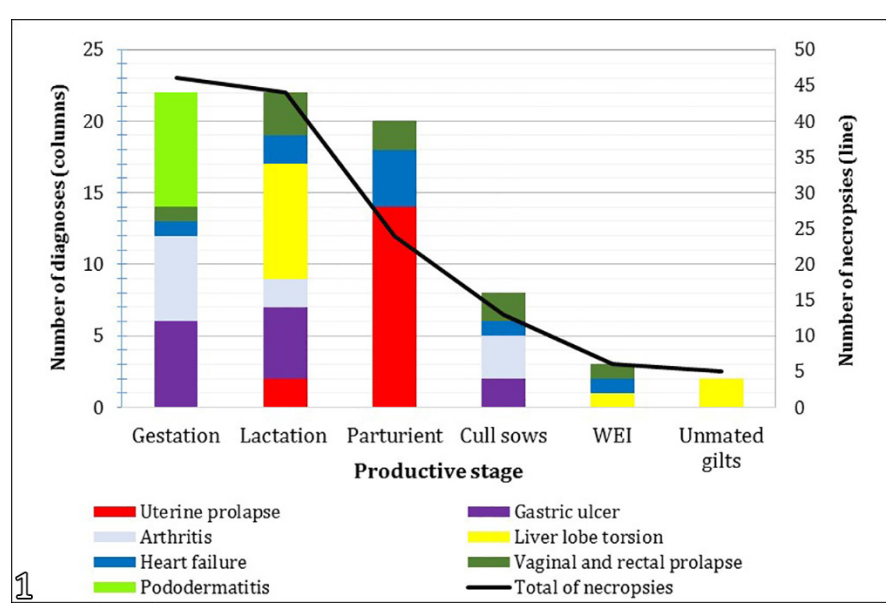

Fig.1. Number of necropsies of sows by productive stage and distribution of the main causes of death diagnosed by productive stage, in three sow operations in Brazil. Weaning-to-estrus interval (WEI). 
the adjacent bone. Frequently, multiple joints were affected, and these sows often had other suppurative lesions, such as cutaneous abscesses and embolic pneumonia.

Similar to suppurative arthritis, liver lobe torsion was also the cause of death in 11 cases. This disease was characterized by sudden death of lactating females (72.7\%) without apparent parity predisposition. When observed, clinical signs were restricted to hyporexia, apathy, and vomiting, present only a few hours before death. Swine affected by this condition usually die of hypovolemic shock, and during necropsy, hemoperitoneum is often observed, due to the rupture of the twisted liver lobe (Fig.6). In all cases, the left lateral lobe was affected, and it was usually twisted by $360^{\circ}$, with variations of up to $720^{\circ}$ (Fig.7). The twisted lobe often had fibrin deposition on the capsule and was enlarged, dark red to black in color, heavy, or otherwise markedly lighter due to the loss of parenchyma after capsular rupture and emphysema.

Heart failure (HF) was the fifth leading cause of death. In all cases, the death was spontaneous. Clinical signs were reported in two cases and restricted to difficulty in breathing, shortly before death. Four of the nine (44.4\%) affected sows were parturient and the other cases were distributed among the other productive stages. In addition to parturition, other stressful and highly demanding physiological episodes that preceded the deaths were fights (2/9), and weaning followed by transference of facilities (2/9). During necropsy, common findings were a mild accumulation of cavitary fluids (ascites, hydrothorax, and hydropericardium), pulmonary edema and congestion, right ventricular chamber dilation (Fig.8), and hepatic congestion. Histological examination showed centrilobular hepatic congestion and pulmonary edema. The histological changes observed in the myocardium were inconsistent among the cases; however, in three of the hearts, there were groups of disorganized fibers, along with a mild proliferation of interstitial fibrous connective tissue.

Nine cases of vaginal prolapse or vaginal and rectal prolapses were seen $(6.8 \%)$. The two structures were prolapsed in six cases $(66.7 \%)$, whereas in three $(33.3 \%)$ the prolapse was only vaginal. There was great variation in the productive stages affected by this condition. Females in lactation were most affected (33.3\%), followed by cull and parturient sows $(22.2 \%$ each). On the necropsy of these sows, prolapsed structures showed marked congestion, in addition to areas of hemorrhage, necrosis and inflammation (Fig.9 and 10). Euthanasia was performed in five (55.6\%) cases. In those that died spontaneously, there was necrosis and traumatic lesions in the prolapsed structures and, less frequently, urinary obstruction and hydronephrosis.

Pododermatitis was the seventh major cause of death identified (6.1\%). All sows were pregnant and of intermediate

Table 1. Causes of death of sows in three Brazilian farms: ranking by organ system, frequency of diagnoses and parity

\begin{tabular}{|c|c|c|c|}
\hline Organ system/conditions & Number of cases & Frequency $(\%)$ & Mean parity (median) \\
\hline Reproductive system & 37 & 28 & $4(3)$ \\
\hline Uterine prolapse & 16 & 12.1 & $5.1(4)$ \\
\hline Vaginal prolapse or vaginal and rectal prolapse & 9 & 6.8 & $3.2(2)$ \\
\hline $\begin{array}{l}\text { Uterine evisceration, mastitis, uterine rupture due to fetal } \\
\text { maceration, laceration of the vulva with ascending metritis }\end{array}$ & 6 & 4.5 & $3.8(3)$ \\
\hline Digestive system & 33 & 25 & $3.1(3)$ \\
\hline Liver lobe torsion & 11 & 8.3 & $2.9(3)$ \\
\hline Acute gastric dilation & 6 & 4.5 & $5.2(5.5)$ \\
\hline Intestinal volvulus, idiopathic rupture of colon, salmonellosis & 3 & 2.3 & $4.3(5)$ \\
\hline Locomotor system & 29 & 22.0 & $3.3(3)$ \\
\hline Suppurative arthritis & 11 & 8.3 & $3.1(3)$ \\
\hline Cardiovascular system & 12 & 9.1 & $3.4(2)$ \\
\hline Heart failure & 9 & 6.8 & $2.9(1)$ \\
\hline Fibrinous pericarditis, endocarditis, uterine artery rupture & 3 & 2.3 & $5(3)$ \\
\hline Hematopoietic system & 8 & 6.1 & $2.9(3.5)$ \\
\hline Splenic torsion & 5 & 3.8 & $3.8(4)$ \\
\hline Splenic rupture, mediastinal lymphoma & 3 & 2.3 & $1.3(0)$ \\
\hline Central nervous system & 6 & 4.5 & $3.8(3)$ \\
\hline Nonsuppurative encephalomyelitis & 4 & 3.0 & $2.7(1.5)$ \\
\hline Ischemic myelopathy caused by fibrocartilaginous embolism & 2 & 1.5 & $6(6)$ \\
\hline Other systems & 7 & 5.3 & $3.3(3)$ \\
\hline
\end{tabular}



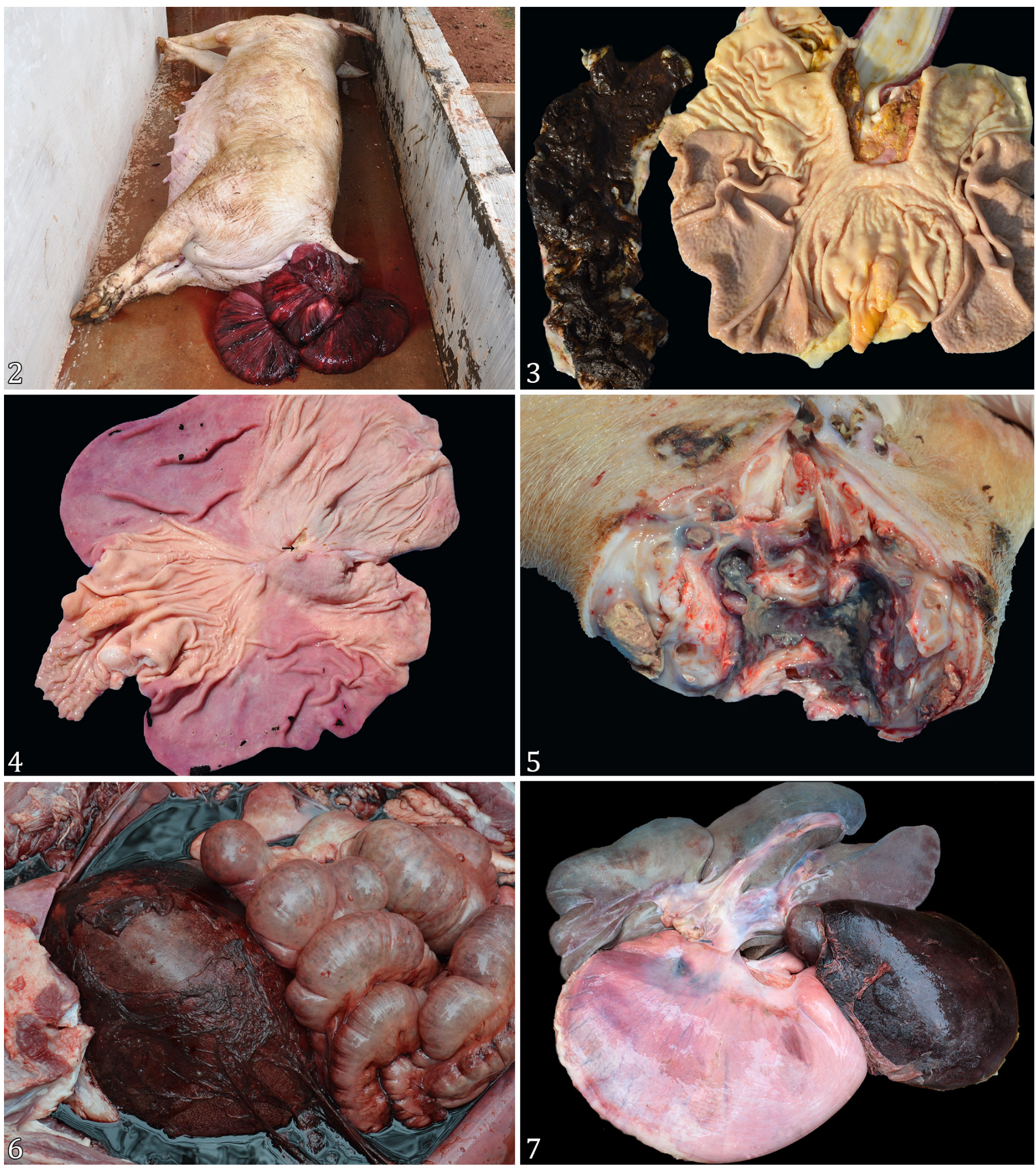

Fig.2-7. Causes of death of sows. (2) Uterine prolapse. Uterus prolapsed through the vulva with mucosal exposure, which is diffusely red (congestion) with areas of hemorrhage and laceration. (3) Gastric ulcer with acute clinical course. There is extensive ulceration of the pars esophagea of the stomach. The large intestine to the left is filled with pasty blackish feces (melena). (4) Chronic gastric ulcer. Note the constriction of the aglandular region and stenosis of the pars esophagea. The remaining cardiac orifice was about $2 \mathrm{~mm}$ in diameter (arrow). (5) Suppurative arthritis in the carpus joint. Deposition of purulent material is observed inside the joint along with gray areas (necrosis and inflammation). (6) Liver lobe torsion. A large amount of blood is observed in the abdominal cavity, in addition to an enlarged hepatic lobe with fibrin on the capsule. (7) Liver lobe torsion. The left lateral lobe is twisted $360^{\circ}$ counter-clockwise. This lobe is enlarged dark red in color, and with fibrin on the capsular surface. 
age (parity 2 to 4 ). Regarding the type of death, five (62.5\%) were submitted to euthanasia and in three (37.5\%), the death was spontaneous, and related to emaciation and dissemination of the foot infection. The foot lesions were characterized by skin ulceration, hock wall cracks, necrosis of the white line, and detachment of the hoof wall (Fig.11). Frequently, extension of the inflammation to the interphalangeal joints and involvement of the tendons and ligaments were seen (Fig.12).

Among the diseases diagnosed less frequently in this study, some aspects stand out. Suppurative discospondylitis and osteochondrosis dissecans (Fig.13) were the reason for euthanasia in three cases each. In the cases of discospondylitis, similar to what occurred in the cases of arthritis, the bacteria Streptococcus spp. (66\%) and T. pyogenes (33\%) were isolated.

Acute gastric dilation (Fig.14), as well as a splenic torsion (Fig.15 and 16), were more frequently observed in lactating sows and were characterized by sudden death. Metritis associated with retained piglets (Fig.17 and 18) was diagnosed in young sows during the first week of lactation and, prior to death, these animals usually presented with apathy, fever, and purulent vaginal discharge. Two cases of peritonitis secondary to rupture of the uterus with macerated fetus (Fig.19) were observed, with death of sows in WEI or after insemination.

\section{DISCUSSION}

The results obtained in this study arose from four periods of data collection and necropsies, which took place during various seasons of the year and in three different farms, located in southern and central-western Brazilian states. Although $58.2 \%$ of the deaths were due to one of the seven most frequent diseases, there was great variability in diagnoses, with more than 30 different conditions diagnosed during the study. The performance of necropsies inside the farms provided a reliable sampling of the diseases that lead sows to death, both spontaneously and through euthanasia, including non-infectious conditions such as prolapses, which are easily identified clinically, making them underrepresented in the laboratories casuistic and consequently in retrospective studies.

Euthanasia was a very common type of death of the sows (36.2\%), specially for sows with locomotor disorders, such as arthritis and pododermatitis, in addition to pelvic organs prolapses (POP). Locomotor disorders accounted for $50 \%$ of euthanasia. High proportions of euthanasia of sows are related not only to economic issues, but also to ethical and animal welfare concerns (Engblom et al. 2007).

The productive stages with the greatest proportion of deaths were gestation and lactation, which are the main productive periods in the life of sows. The proportion of females that died during gestation (33.3\%) and lactation (31.9\%) was similar, but in a pig farm, the population of pregnant sows is always larger; therefore, it has to be considered that the sows are more likely to die during lactation than during gestation (Kirk et al. 2005, Sanz et al. 2007). If the parturient and lactation stages are added, $49.3 \%$ of the deaths occurred in females in the farrowing facility. The third greatest number of deaths occurred in the parturient productive stage, driven by the high occurrence of prolapses. The peripartum period is considered a period of risk and in one study it comprised $42.1 \%$ of sow deaths, mainly due to the high incidence of heart failure (Chagnon et al. 1991).
The category cull sows accounted for $9.4 \%$ of all necropsies performed, a high proportion, since this category is not even considered in other studies (Chagnon et al. 1991, Vearick et al. 2008). These sows had been removed from breeding due to health or zootechnical criteria, and were waiting to be sent for slaughter. The sows that presented with a deterioration in their clinical condition, or were diagnosed with diseases that made it impossible to transport them to the slaughterhouse, were submitted to euthanasia.

The mean parity at death was 3.4 (median 3). This data shows great variation with other studies performed in different countries, in which the parity of removal from the herd or death ranged from 2.27 to 4.2 (Chagnon et al. 1991, Lucia Jr. et al 2000a, Karg \& Bilkei 2002, Sanz et al. 2007, Engblom et al. 2008). Under conventional breeding conditions, a sow returns the investment received after the third farrowing, on average (Lucia Jr. et al. 2000b, Engblom et al. 2007). In this study, $42 \%$ of necropsied sows had not reached parity 3 . Sow mortality has a direct implication on the replacement rate, which must be kept between 40 and $45 \%$ per year, in order to maintain the optimal parity distribution, which allows to concentrate as many as possible sows in the most productive phase, between three and six farrowings (Lucia Jr. et al. 2000a, Antunes 2007).

Prolapses of the uterus, vagina, and rectum have been implicated as causes of death of secondary importance in previous surveys (Chagnon et al. 1991, D’Allaire et al. 1991, Engblom et al. 2008, Vearick et al. 2008); however, its occurrence has increased greatly in recent years (Alberton et al. 2017, Supakorn et al. 2017). If added, prolapses of the uterus, vagina, and both the vagina and rectum, constituted $18.9 \%$ of sow deaths in this study. Prolapses are responsible for 25 to $50 \%$ of the mortality of sows in some farms in the United States, where it is a major concern (Pittman 2016). Some factors are suspected to be associated with the increase of prolapse occurrence in sows, but investigations that seek to elucidate the issue are scarce. A study that sought to determine some putative contributing factors for the occurrence of pelvic organ prolapse (POP), found out that water treatment on the farm and feeding strategy prior to farrowing were important to reduce it, once sows with lowest body condition score had a greater probability of experience POP. In the same study, herd size, induction and farrowing assistance protocols were potentially, although not proven, influencing POP (Chipman et al. 2018). In our study, uterine prolapses frequently occurred in high parity sows, similar to other studies (Chagnon et al. 1991, Iida et al. 2019). These older sows may be predisposed due to a larger pelvic inlet, an excessive relaxation of the pelvic and perineal regions, and loss of uterine tone (Chagnon et al. 1991, Iida et al. 2019).

Gastric ulcer was the second most frequent cause of death of sows in this study, with $9.8 \%$ of the conclusive diagnoses. In another study conducted in Brazil, $14.1 \%$ of sow deaths were attributed to gastric ulcers (Vearick et al. 2008). In other surveys, gastric ulcer as the cause of death in sows is generally less than 5\% of cases (Chagnon et al. 1991, D'Allaire et al. 1991, Kirk et al. 2005). In growing-finishing pigs the gastric ulcers are a major problem, because they prevent weight gain (Thomson \& Friendship 2012) and also because they lead pigs to death. In a recent study, gastric ulcer was the cause of death of $15.4 \%$ of 601 growing-finishing pigs subjected 

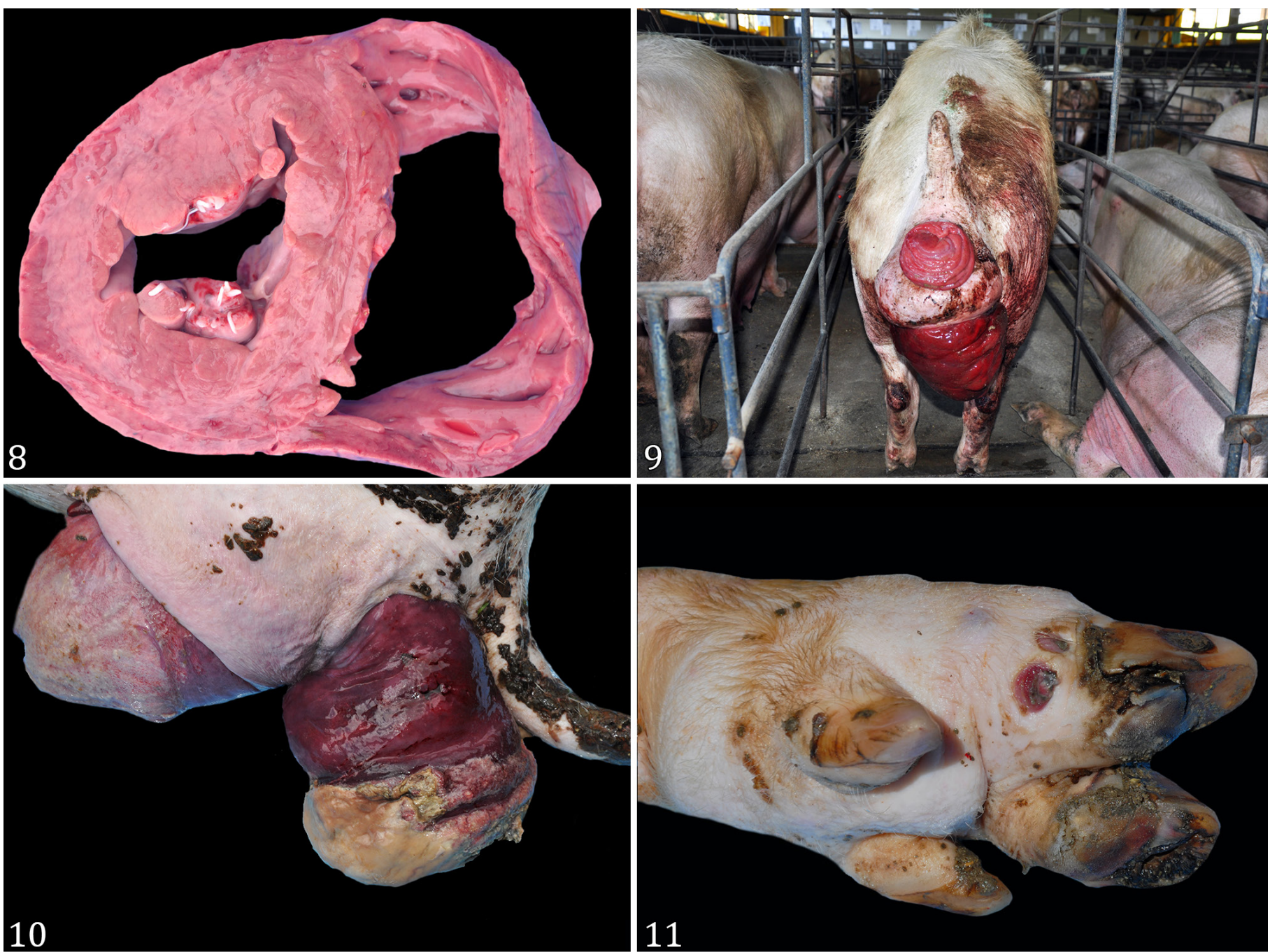

\section{0}
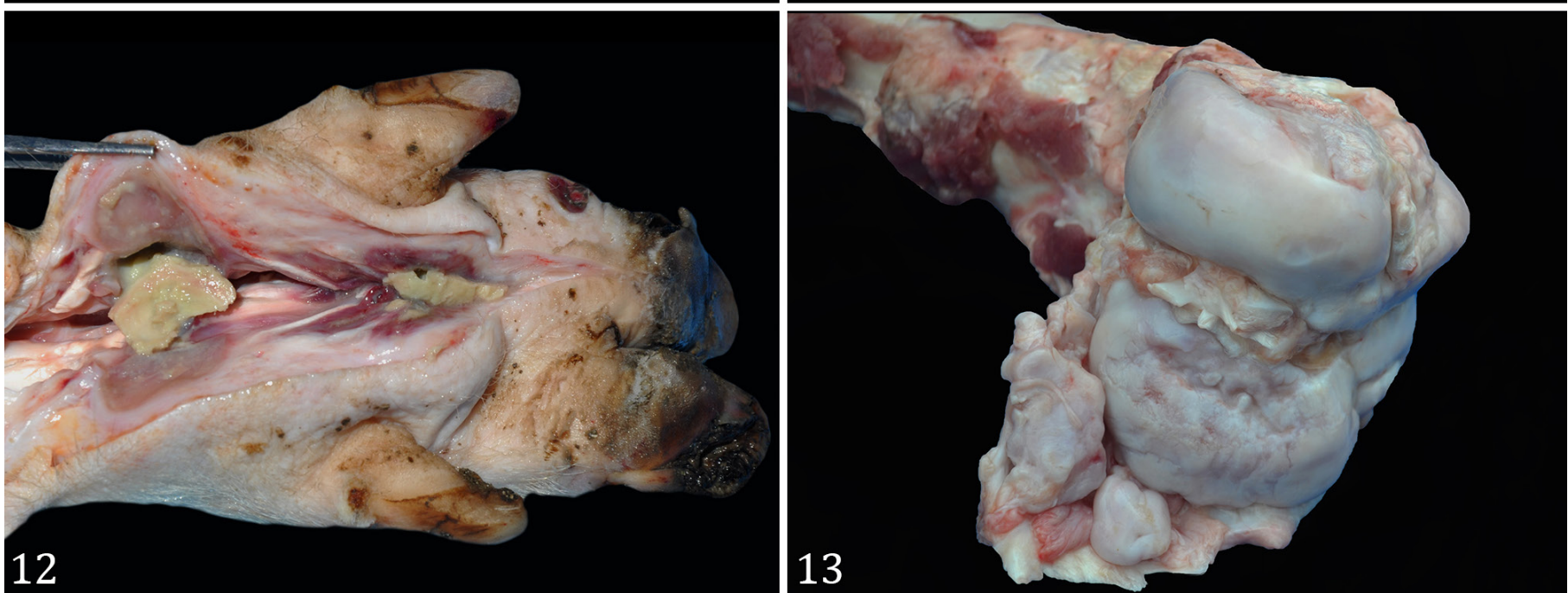

Fig.8-13. Causes of death of sows. (8) Heart failure. Heart with moderate dilatation of the right ventricular chamber. Areas of hemorrhage in the left ventricular endocardium are also present. (9) Prolapse of the vagina and rectum. Prolapsed structures are congested and enlarged. (10) Prolapse of the vagina and rectum. The prolapsed structures are congested and areas of mucosal laceration are observed, in addition to necrosis and fibrin deposition. (11) Pododermatitis in the left thoracic limb. There is an increase in volume between the dew claws, in addition to areas of skin ulceration, hock wall cracks, necrosis of the white line, and partial detachment of the hoof wall. (12) Pododermatitis. Same sow as in the previous photo. Purulent content is observed between the interphalangeal joints (arthritis), and around the tendons (tendinitis and tenovaginitis) and ligaments. (13) Osteochondrosis dissecans in the femur. Multiple areas of depression and irregularity of the surface of the condyles are observed, as well as two fragments of bone that have broken off. 

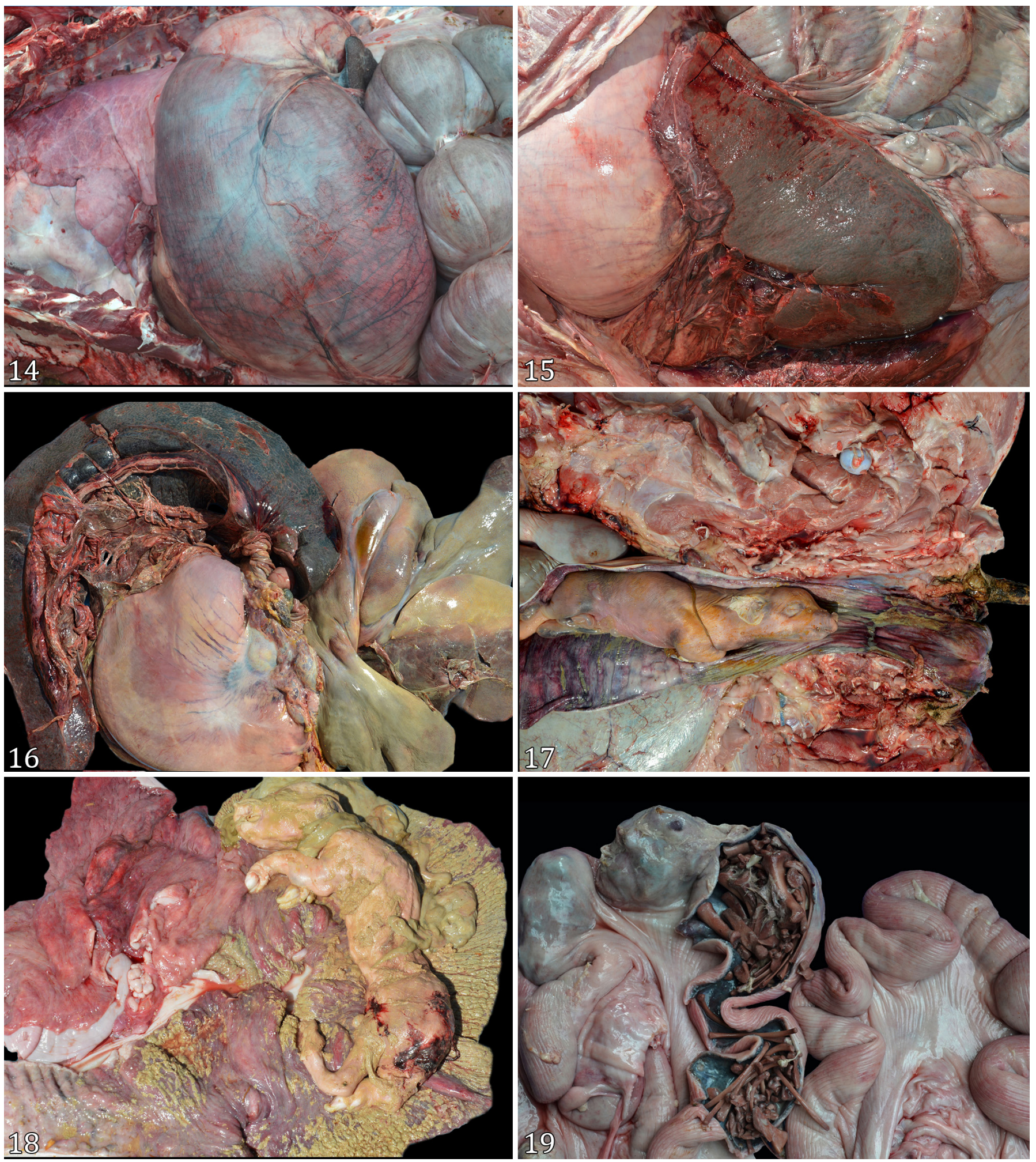

Fig.14-19. Causes of death of sows. (14) Acute gastric dilation. Stomach distended by gas and food content. The stomach wall is dark red with blood vessels evident and discrete multifocal areas of hemorrhage. (15) Splenic torsion. The spleen is displaced ventrolaterally, severely increased in volume, with extensive adherence to the stomach and intestines. (16) Splenic torsion. The spleen is twisted $360^{\circ}$ clockwise and is enlarged and darkened. (17) Metritis associated with fetal retention (dystocia). A piglet is observed to be obstructing the birth canal at the transition between the abdominal and pelvic cavities. There are also marked multifocal areas of yellowish color in the mucosa of the vagina and uterus, which correspond to necrosis and inflammation. (18) Metritis associated with fetal retention. Note the fetus in an advanced state of autolysis and wrapped in the remains of the placenta. Extensive yellowish areas of necrosis and inflammation are observed on the uterine mucosa. (19) Peritonitis due to rupture of the uterus with macerated fetus. In the uterine horn, multiple bones resulting from fetal maceration are observed. On the serosa, there is a mild deposition of fibrin. 
to necropsy (Piva et al. 2020). In our study, the clinical and pathological presentation of this disease agreed with the descriptions in the available literature, with gastric ulcers being incriminated as the cause of sudden death and even as a chronic and cachetizing condition (Friendship 2004, Thomson \& Friendship 2012). Gastric ulcer is a multifactorial disease and its onset is associated with environmental, management, nutritional, and stress factors, which usually act in multiple or associated ways. Feed composition and particle size, as well as feed restriction, are reported important predisposing factors (Melnichouk 2002, Thomson \& Friendship 2012).

Suppurative arthritis was an important cause of death in this study, mainly due to the euthanasia of sows with locomotor deficit. This condition is a frequent reason for the euthanasia of sows and was the main cause of death in two studies, with $16.8 \%$ (Sanz et al. 2007) and $36.4 \%$ of the diagnoses (Engblom et al. 2008). In another study, locomotor problems were the main cause of euthanasia of sows, with a frequency of $72 \%$, whereas arthritis alone accounted for $24 \%$ of euthanasias (Kirk et al. 2005).

Trueperella pyogenes and Streptococcus spp. were the most commonly isolated bacteria, similar to what was observed in another study (Kirk et al. 2005). T. pyogenes is a normal mucosal inhabitant, which serves as an autogenous source for opportunistic infections in animals. Although $T$. pyogenes is capable of acting as a primary pathogen, infection often follows a physical or microbial trauma to the mucous membrane, allowing dissemination of the organism (Jost \& Billington 2005). Injuries due to farrowing, fights, accidents with facilities and endometritis may be possible infection gateways.

Liver lobe torsion was an important cause of spontaneous death in lactating sows. When all the abdominal organ accidents were assessed (liver lobe torsion, splenic torsion or rupture, acute gastric dilation, and intestinal volvulus or rupture), $65.4 \%(17 / 26)$ occurred during lactation, and of those, $64.7 \%(11 / 17)$ were liver lobe torsions. Other studies have pointed out this disease as a cause of death of sows, but not in such a large proportion (Chagnon et al. 1991, Sanford et al. 1994, Kirk et al. 2005). Among the abdominal organ accidents, torsion and dilation of the stomach, and splenic torsion are the most commonly diagnosed in pigs (Morin et al. 1984, Sanford et al. 1994). In pigs, the left lateral liver lobe is the largest of the hepatic lobes and it is connected to the left medial lobe by a relatively thin band of tissue. This arrangement makes the left lateral lobe quite mobile, and therefore, predisposed to twisting (Hamir 1980). The apparent predisposition for this disease in lactating sows is reported in other studies (Hamir 1980) and is possibly related to the intense management and increased food intake during this phase, when the sows become more agitated, lie down and stand up several times to eat and nurse the piglets. Feed frequency and volume may be related to this condition, as has been described for torsions in other organs (Morin et al. 1984, Abiven et al. 1998).

Heart failure (HF) is described as the leading cause of death of sows in some studies, with a frequency of up to 31\% (Chagnon et al. 1991, D'Allaire et al. 1991). In Brazil, a previous study reported a frequency of $10.3 \%$ (Vearick et al. 2008). The diagnosis of HF may be difficult to establish, particularly in acute cases, such as those observed in this study. The presence of lesions that indicate HF (mucosal cyanosis, fluid in the pericardial, thoracic and abdominal cavities, cardiac chambers changes, pulmonary edema and passive congestion in the lung and liver) should be taken into consideration, together with the absence of pathological and microbiological findings suggestive of other diseases (D'Allaire et al. 1991). The parturition, heat, fights, breeding, and transport are known as triggering factors (D'Allaire et al. 1991, Drolet et al. 1992).

Pododermatitis was the second major cause of death among the conditions of the locomotor system, and the seventh leading cause of death in general. In another study, approximately $5 \%$ of euthanasia of sows was due to foot injuries (Kirk et al. 2005). Although not always related to the cause of death, foot injuries are very frequent, and up to $99 \%$ of sows may present with at least one lesion (Kirk et al. 2005). Thus, foot lesions and lameness are important reasons for culling, as well as insufficient reproductive performance, which is also related to locomotor problems (Wilson et al. 2009). The foot injuries have a multifactorial origin and several predisposing factors have been reported, especially the quality of the floor of facilities, rapid growth of the pigs, housing systems, management, and nutritional aspects (Kroneman et al. 1993).

Infectious diseases represented infrequent causes of death of sows in this study. In other studies carried out in Brazil, infectious diseases were responsible for the majority of deaths of weaned and growing-to-finishing pigs (Brum et al. 2013, Piva et al. 2020), and were also very common in sows (Vearick et al. 2008). In the study of Vearick et al. (2008) the genitourinary infections were the most frequent cause of death of sows, with $30.8 \%$ of the diagnosis. This condition was not diagnosed in this study, which may indicate the efficacy of the protocols of prevention and control.

\section{CONCLUSIONS}

The deaths of sows in this study were mainly attributed to noninfectious and multifactorial diseases, which most frequently affected the reproductive, digestive, and locomotor systems.

Many conditions leading to euthanasia or spontaneous death were diagnosed and these diagnoses should be considered when establishing control measures to reduce sow mortality.

Acknowledgements.- The authors would like to thank the "Coordenação de Aperfeiçoamento de Pessoal de Nível Superior" (CAPES) for financial support, and Gustavo Geraldo Medina Snel and Bruna Corrêa López for their technical assistance for the bacteriological analysis.

Conflict of interest statement.- The author(s) declared no potential conflicts of interest with respect to the research, authorship, and/or publication of this article.

\section{REFERENCES}

Abiven N., Seegers H., Beaudeau F., Laval A. \& Fourichon C. 1998. Risk factors for high sow mortality in French swine herds. Prev. Vet. Med. 33(1/4):109-119. <https://dx.doi.org/10.1016/S0167-5877(97)00053-6><PMid:9500168>

Alberton G.C., Cestari F.K., Silva L.C.S. \& Donin D.G. 2017. O problema dos prolapsos uterinos em matrizes suínas. Anais do X Simpósio Internacional de Suinocultura (SINSUI), Porto Alegre, RS, p.175-180. (Resumo)

Antunes R.C. 2007. Planejamento a reposição de reprodutores (macho e fêmea) e impacto sobre a eficiência reprodutiva da granja. Revta Bras. Reprod. Anim. 31(1):41-46. 
Brum J.S., Konradt G., Bazzi T., Fighera R.A., Kommers G.D., Irigoyen L.F. \& Barros C.S.L. 2013. Características e frequência das doenças de suínos na Região Central do Rio Grande do Sul. Pesq. Vet. Bras. 33(10):1208-1214. <https://dx.doi.org/10.1590/S0100-736X2013001000006>

Chagnon M., D’Allaire S. \& Drolet R. 1991. A prospective study of sow mortality in breeding herds. Can. J. Vet. Res. 55(2):180-184. <PMid:1884299>

Chipman A.L., Rademacher C.J., Johnson C.D., Stalder K.J., Johnson A.K., Keating A.F., Patience J.F., Gabler N.K., Linhares D.C.L., Schwartz K.J., Millman S.T., Studer J.M., Kiefer Z.E., Silva G. \& Ross J.W. 2018. Pelvic organ prolapse: an industry-wide collaboration to identify putative contributing factors. Animal Science Conference Proceedings and Presentations. 47, Ames, IA, p. 57-60.

D’Allaire S., Drolet R. \& Chagnon M. 1991. The causes of sow mortality: a retrospective study. Can. Vet. J. 32(4):241-243. <PMid:17423771>

Drolet R., D’Allaire S. \& Chagnon M. 1992. Some observations on cardiac failure in sows. Can. Vet. J. 33(5):325-329. <PMid:17424001>

Engblom L., Eliasson-Selling L., Lundeheim N., Belák K., Andersson K. \& Dalin A.-M. 2008. Post mortem findings in sows and gilts euthanised or found dead in a large Swedish herd. Acta Vet. Scand. 50(1):25. <https:// doi.org/10.1186/1751-0147-50-25><PMid:18593470>

Engblom L., Lundeheim N., Dalin A.-M. \& Anderson K. 2007. Sow removal in Swedish commercial herds. Livest. Sci. 106(1):76-86. <https://dx.doi. $\operatorname{org} / 10.1016 / j . l i v s c i .2006 .07 .002>$

Friendship R.M. 2004. Gastric ulcerations in swine. J. Swine Health Prod. 12(1):34-35.

Hamir A.N. 1980. Torsion of the liver in sow. Vet. Rec. 106(16):362-363. <https://dx.doi.org/10.1136/vr.106.16.362><PMid:7376394>

Iida R., Piñeiro C. \& Koketsu Y. 2019. Incidences and risk factors for prolapse removal in Spanish sow herds. Prev. Vet. Med. 163:79-86. <https://dx.doi. org/10.1016/j.prevetmed.2018.12.016><PMid:30670190>

Jost B.H. \& Billington S.J. 2005. Arcanobacterium pyogenes: molecular pathogenesis of an animal opportunist. Antonie Van Leeuwenhoek. 88(2):87102. <https://dx.doi.org/10.1007/s10482-005-2316-5><PMid:16096685>

Karg H. \& Bilkei G. 2002. Causes of sow mortality in Hungarian indoor and outdoor pig production units. Berl. Munch. Tierarztl. Wochenschr. 115(9/10):366-368. <PMid:12357674>

Kirk R.K., Svensmark B., Ellegaard L.P. \& Jensen H.E. 2005. Locomotive disorders associated with sow mortality in Danish pig herds. J. Vet. Med. 52(8):423-428. <https://dx.doi.org/10.1111/j.1439-0442.2005.00747.x> $<$ PMid:16176574>

Kroneman A., Vellenga L., Van der Wilt F.J. \& Vermeer H.M. 1993. Review of health problems in group-housed sows, with special emphasis on lameness. Vet Q. 15(1):26-29. <https://dx.doi.org/10.1080/01652176.1993.9694364> <PMid:8498012>

Lucia Jr. T., Dial G.D. \& Marsh W.E. 2000a. Lifetime reproductive performance in female pigs having distinct reason for removal. Livest. Prod. Sci. 63(3):213222. <https://dx.doi.org/10.1016/S0301-6226(99)00142-6>
Lucia Jr. T., Dial G.D. \& Marsh W.E. 2000b. Lifetime reproductive and financial performance of female swine. J. Am. Vet. Med. Assoc. 216(11):1802-1809. <https://dx.doi.org/10.2460/javma.2000.216.1802><PMid:10844975>

Melnichouk S.I. 2002. Mortality associated with gastric ulceration in swine. Can. Vet. J. 43(3):223-225. <PMid:11901598>

Morés N. 2007. Mortes de matrizes em granjas de suínos. Acta Sci. Vet. 35(Supl.):S1-S8.

Morin M., Sauvageau R., Phaneuf J-B., Teuscher E., Beauregard M. \& Lagacé A. 1984. Torsion of abdominal organs in sows: a report of 36 cases. Can. Vet. J. 25(12):440-442. <PMid:17422483>

Palomo A. 2006. Analysis of sow mortality among breeding sows in Spanish pig breeds. Proceedings of 2006 Allen D. Leman Swine Conference, University of Minnesota, St. Paul, MN. Available at <https://conservancy. umn.edu/bitstream/handle/11299/157276/Palomo.pdf?sequence=1> Accessed on Jan. 30, 2018.

Pittman J.S. 2016. Sow prolapse syndrome. Proceedings of 2016 ISU James D. McKean Swine Disease Conference, Ames, IA, p.45-58. Available at <file://C:/Users/Regina/Downloads/(Pittman\%202016)\%20Sow\%20 Prolapse\%20 syndrome.pdf> Accessed on Jan. 30, 2018.

Piva M.M., Schwertz C.I., Bianchi R.M., Kemper R.T., Henker L.C., Nagae R.Y., Cê T.R.M., Barcellos D.E.S.N., Driemeier D. \& Pavarini S.P. 2020. Causes of death in growingfinishing pigs in two technified farms in southern Brazil. Pesq. Vet. Bras. 40(10):758-775. <https://dx.doi.org/10.1590/16785150-PVB-6708>

Sanford S.E., Josephson G.K.A. \& Rehmtulla A.J. 1994. Sudden death in sows. Can. Vet. J. 35(6):338. <PMid:8069844>

Sanz M., Roberts J.D., Perfumo C.J., Alvarez R.M., Donavan T. \& Almond G.W. 2007. Assessment of sow mortality in a large herd. J. Swine Health Prod. 15(1):30-36.

Supakorn C., Stock J.D., Hostetler C. \& Stalder K.J. 2017. Prolapse incidence in swine breeding herds is a cause for concern. Open J. Vet. Med. 7:85-97. <https://dx.doi.org/10.4236/ojvm.2017.78009>

Thomson J.R. \& Friendship R.M. 2012. Digestive system, p.199-226. In: Zimmerman J.J., Karriker L.A., Ramirez A., Schwartz K.J. \& Stevenson G.W. (Eds), Diseases of Swine. 10th ed. Blackwell Publishing, Iowa.

Vearick G., Mellagi A.P.G., Bortolozzo F.P., Wentz I. \& Bernardi M.L. 2008. Causas associadas à morte de matrizes suínas. Arch. Vet. Sci. 13(2):126132. <https://dx.doi.org/10.5380/avs.v13i2.12893>

Wilson M.E., Ward T.L. \& Rapp C. 2009. Lameness hurts sow reproduction. Proceedings of 2009 Allen D. Lemon Swine Conference, University of Minnesota, St. Paul, MN. Available at <https://conservancy.umn.edu/ bitstream/handle/11299/139774/Wilson.pdf?sequence=1>. Accessed on Jan. 30, 2018. 